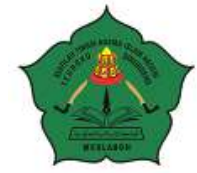

AT-TASYRI' Jurnal Ilmiah Prodi Muamalah

P-ISSN: 2085-2541, E-ISSN: 2715-7865

Volume 13, Nomor 2, Desember 2021

https://ejournal.staindirundeng.ac.id/index.php/Tasyri

\title{
PRODUKTIVITAS USAHA MINYAK NILAM SIDO MULYO ACEH UTARA DALAM PERPESKTIF EKONOMI ISLAM
}

\author{
Husni Kamal* \\ Institut Agama Islam Negeri Lhokseumawe \\ *husnikamal@iainlhokseumawe.ac.id \\ Muhammad Syafril Nasution \\ Institut Agama Islam Negeri Lhokseumawe \\ muhammadsyafrilnst@iainlhokseumawe.ac.id
}

\begin{abstract}
Abstrak
Produktivitas merupakan faktor utama yang bisa mempengaruhi kesanggupan bersaing dalam dunia usaha, dengan meningkatkan produktivitas maka kesejahteraan akan didapatkan serta dapat mengurangi angka kemiskinan di daerah. Penelitian yaitu Untuk mengetahui Produktivitas usaha minyak nilam di Desa Sido Mulyo Kecamatan Kuta Makmur Kabupaten Aceh Utara dalam perspektif Ekonomi Islam. Metode yang digunakan dalam penelitian ini yaitu kualitatif dengan pendekatan studi lapangan dengan melakukan mewawancara dengan pihak terkait. Hasil penelitian memberikan kesimpulan bahwa kurangnya produksi dan inovasi dalam pengolahan minyak nilam, padahal dalam islam sangat menganjurkan produktivitas usaha untuk meningkatkan kesejahteraan.
\end{abstract}

Kata Kunci: Produktivitas, Minyak Nilam, Ekonomi Islam

\begin{abstract}
Productivity is the main factor that can affect the ability to compete in the business world, by increasing productivity, welfare will be obtained and can reduce poverty in the region. The research is to find out the productivity of patchouli oil business in Sido Mulyo Village, Kuta Makmur District, North Aceh Regency in the perspective of Islamic Economics. The method used in this research is qualitative with a field study approach by conducting interviews with related parties. The results of the study conclude that there is a lack of production and innovation in patchouli oil processing, whereas Islam strongly recommends business productivity to improve welfare
\end{abstract}

Keywords: Productivity, Patchouli Oil, Islamic Economy

A. PENDAHULUAN

Zaman yang semakin canggih menuntut manusia supaya semakin berkembang dalam bidang manapun, baik dalam teknologi maupun dalam pemanfaatan sumber daya alam. Indonesia merupakan sebuah negara berkembang yang selalu berupaya untuk menciptakan kesejahteraan masyarakatnya agar dapat mengurangi angka kemiskinan, baik dari sektor ekonomi, produksi maupun dari sektor sumber daya manusia yang produktif.

Berbicara tentang pembangunan dan perkembangan ekonomi dalam masyarakat pastinya hal yang harus diberi perhatian adalah pelaksanaan kegiatan ekonomi sesuai dengan potensi dan kemampuan yang ada 
dalam lingkungan masyarakat tersebut. Setiap individu menginginkan kondisi hidup dimasa yang akan datang bisa lebih baik dari masa sebelumnya. Kondisi yang lebih baik tersebut yaitu untuk tercapainya tingkat kesejahteraan dalam hidup yang lebih tingi, yaitu semakin banyak tuntutan kebutuhan hidup yang harus dipenuhi apalagi saat pandemi seperti ini dimana perekonomian terjadi penurunan. Oleh karena itu, dalam setiap masyarakat adanya tersedia sumber daya yang merupakan sebuah potensi yang harus dimaksimalkan untuk memenuhi kebutuhan hidup.

Dalam mengidentifikasi potensi dan sumber daya yang terdapat dalam masyarakat merupakan langkah yang sangat penting dalam keswadayaan masyarakat yang lebih mengutamakan potensi dan sumber daya lokal yang dimiliki oleh daerah serta diperlukannya perhatian pemerintah. Potensi tersebut yaitu semua potensi yang ada seperti sumber daya alam, sumber daya manusia serta sumber daya sosial (Soetomo, 2012).

Kegiatan produksi yaitu salah satu aktifitas ekonomi yang sangat menunjang kegiatan lainnya selain kegiatan konsumsi dan distribusi. Kegiatan konsumsi, distribusi dan produksi merupakan mata rantai yang saling berhubungan dan tidak bisa dipisahkan antara satu dengan yang lain. Produksi merupakan sebuah kegiatan yang dilakukan untuk menghasilkan suatu produk baik barang, maupun jasa yang selanjutnya di manfaatkan oleh konsumen atau masyarakat. Selain itu, produksi juga merupakan segala kegiatan dalam menciptakan dan menambah kegunaan (utility) sesuatu barang atau jasa (Rianto, 2010).

Dalam bidang produksi, sektor pertanian merupakan bidang yang sangat menjanjikan dan harus menjadi perhatian pemerintah baik pusat maupun daerah untuk output yang bisa dihasilkan apalagi Indonesia merupakan sebuah Negara yang agraris. Pada saat Indonesia mengalami krisis ekonomi sektor pertanian menjadi sebuah pengharapan besar dan tameng besar sebagai pemulihan ekonomi serta menjadi sumber pendapatan untuk Negara dimana saat mengalami krisis saat itu. Umumnya, komoditas itu berasal dari perkebunan, salah satunya yaitu bersumber dari Minyak Nilam. Minyak Nilam merupakan output tanaman tradisional yang banyak dipakai dalam pengolahan industri kimia menjadi salah satu bahan baku produk wewangian (parfum), farmasi, kosmetika, pengawetan barang, dan kebutuhan dasar industri lainnya.

Aceh merupakan sebuah provinsi yang mempunyai kekayaan alam yang sangat melimpah sehingga dikenal oleh Negara lain, salah satunya nilam yang mempunyai banyak manfaat sebagai bahan baku industri. Kualitas nilam di Aceh juga diakui oleh berbagai Negara, bahkan masuk ke dalam 5 besar kualitas mutu nilam di dunia dan pernah mengalami masa kejayaannya sehingga sangat berdampak terhadap perekonomian para petani nilam.

Menurut wakil ketua Kontak Tani Nelayan Andalan (KTNA) Aceh Tamiang yang dilansir dari Waspada (Syahrial, 2021), Negara luar sangat tertarik dengan kualitas nilam yang dimiliki Aceh dikarenakan memiliki kandungan Patcholi Alkohol diatas 30\% serta dipengaruhi oleh tanah yang sangat cocok untuk dibudidaya tanaman nilam.

Adapun jumlah produksi nilam dari tahun 2017 s.d 2021 mengalami peningkatan khususnya di provinsi Aceh. Berdasarkan data statistik pertanian didapatkan yaitu: 
Tabel. 1. Produksi Nilam Tahun 2017-2021 Provinsi Aceh

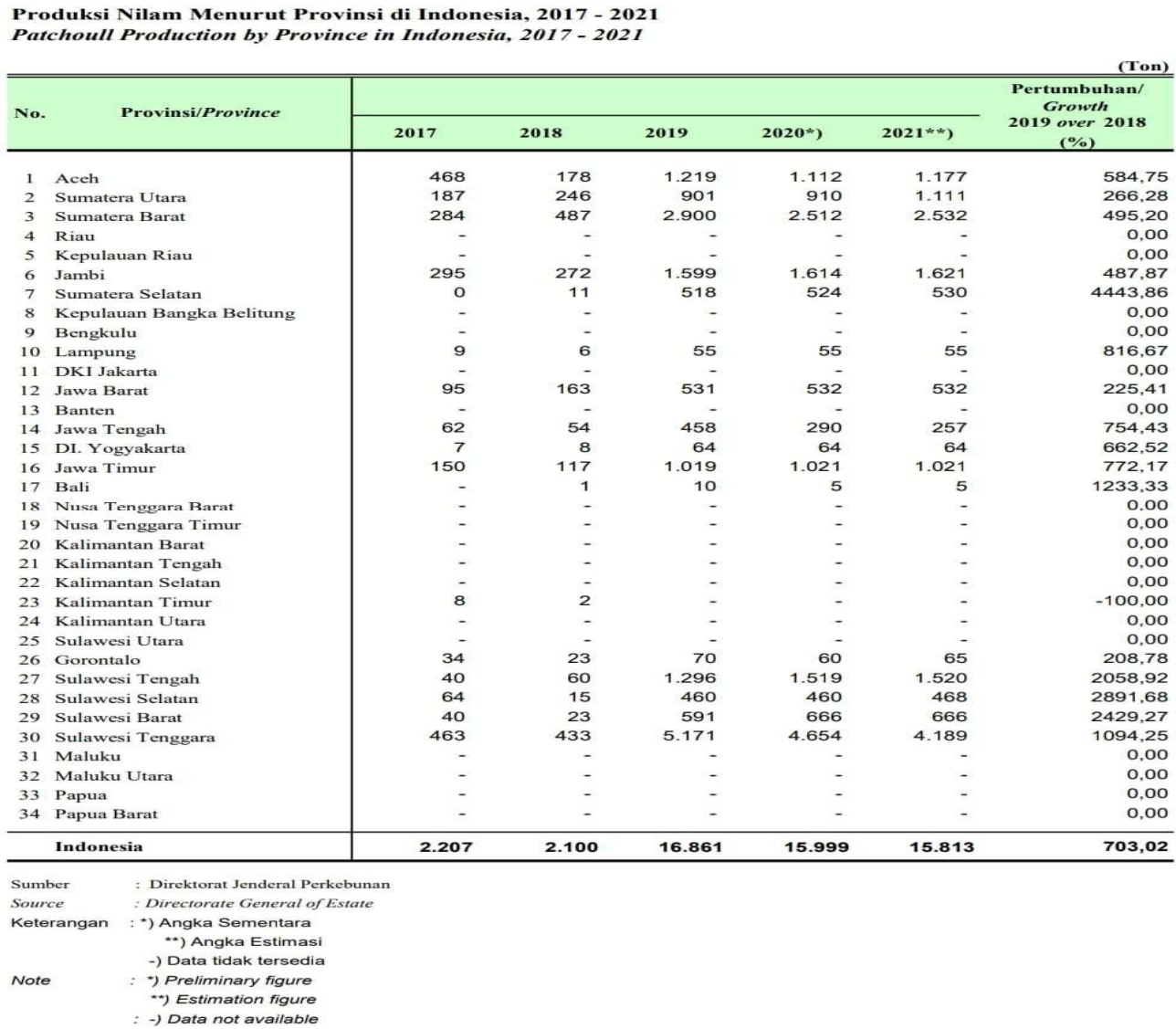

Berdasarkan data dari tabel diatas (Pertanian, 2021), maka dapat diketahui bahwa jumlah produksi minyak nilam di provinsi Aceh sudah mulai di tingkatkan dan itu terlihat dari jumlah produksi disetiap tahunnya mengalami peningkatan walaupun pada tahun 2018 sempat mengalami penurunan namun pada tahun selanjutnya mengalami kenaikan, akan tetapi bentuk produksi minyak nilam sudah terlihat bagi perekonomian masyarakat di provinsi Aceh.

Dilihat dari keunggulan Minyak Nilam selain bermanfaat bagi berbagai ragam kebutuhan industri dan masa panennya relatif singkat dan mempunyai jangka waktu hidup yang cukup lama, proses pemeliharaan, pengendalian tanaman relative mudah dan prospeknya bagus. Oleh karena itu sebagian petani di Desa Sido Mulyo Kecamatan Kuta Makmur
Kabupaten Aceh Utara sejak tahun 2016 sudah mulai fokus menanam Nilam.

Setiap usaha yang dilakukan rentan dari berbagai masalah atau tantangan salah satunya petani minyak Nilam di Desa Sido Mulyo dimana produksi yang dimiliki belum maksimal dikarenakan sumber daya manusia yang dimiliki belum mempunyai skill yang lebih baik dari segi produksi, ditambah lagi mesin penyulingan minyak nilam hanya dimiliki satu, sehingga para petani minyak nilam harus mengantri dalam melakukan penyulingan akibatnya proses produksi membutuhkan waktu lama sehingga sangat berpengaruh terhadap produktivitas masyarakat.

Produktivitas merupakan faktor utama yang bisa mempengaruhi kesanggupan bersaing dalam dunia usaha, dengan meningkatkan produktivitas maka 
kesejahteraan akan didapatkan serta dapat mengurangi angka kemiskinan di daerah tersebut. Aceh merupakan salah satu provinsi yang sangat berpotensi untuk menghasilkan nilam dikarena faktor alamnya.

Dalam Islam terkait Produktivitas sangat diperhatikan karena akan mempengaruhi kesejahteraan seseorang serta dapat mengurangi angka kemiskinan (Anwar, 2020). Islam menganjurkan seorang muslim agar mengerjakan sesuatu dengan prestasi yang baik karena akan bermanfaat untuk dirinya dan juga untuk orang lain secara tidak langsung. Islam mengajarkan seorang muslim untuk menjadi seorang yang sukses dan kaya, namun masih banyak yang belum bisa membedakan antara konsep zuhud dan tawakkal sehingga dalam berusaha hanya memasrahkan diri terhadap usaha tersebut tanpa diikuti dengan usaha yang maksimal yang akhirnya mengurangi produktivitas dan penurunan kesejahteraan.

\section{B. METODE PENELITIAN}

Penelitian ini menggunakan jenis penelitian kualitatif dengan menggunakan pendekatan studi lapangan di daerah Sido Mulyo. Untuk mendapatkan data yang relevan dengan permasalahan data yang digunakan dari data primer dan data sekunder. Yang menjadi data primer disini yaitu dengan melakukan wawancara dengan kelompok tani dan petani nilam yang terdapat di Sido Mulyo. Sedangkan data sekunder didapatkan bersumber dari buku, jurnal dan tulisan pakar mengenai produktivitas.

\section{HASIL DAN PEMBAHASAN}

Produksi merupakan bagian dari usaha produktivitas, yang dimaksud dengan Produksi atau memproduksi yaitu menambah kegunaan atau nilai guna dalam suatu barang. Kegunaan suatu barang akan bertambah jika dapat memberikan manfaat baru atau lebih dari bentuk semula. Untuk memproduksi sesuatu dibutuhkan faktorfaktor produksi, yaitu alat atau sarana dalam melakukan proses produksi. Fungsi produksi yaitu hubungan teknis antara faktor produksi (input) dan hasil produksi (output) (Muhammad, 2004).

Adapun faktor-faktor produksi meliputi, tenaga kerja, modal, sumber daya alam, skill/teknologi. Fungsi produksi adalah hubungan teknis antara faktor produksi ( input) dan hasil produksi ( output ). Hal ini berarti bahwa produksi hanya bisa dilakukan dengan menggunakan faktorfaktor produksi yang dimaksud, bila faktor produksi tidak ada maka tidak ada proses produksi. Produksi yang menggunakan faktor alam disebut dengan produksi alami. Jika produksi dilakukan dengan manipulasi faktor-faktor produksi disebut produksi rekayasa. Sedangkan proses produksi merupakan suatu proses kegiatan yang mengubah bahan baku menjadi barang lain yang mempunyai nilai tambah lebih tinggi. Istilah proses produksi dalam bahasa Inggris adalah manufacture atau diterjemahkan menjadi manufaktur. ${ }^{9}$ Secara umum produksi yaitu berhubungan dengan hasil keluaran sedangkan produktivitas mengenai efisiensi penggunaan sumber daya.

Produktivitas memiliki makna yang berbeda-beda tergantung dengan kesesuaian pemakaiannya, secara umum dapat dijelaskan yaitu hubungan antara keluaran (barang dan jasa) dengan masukan (bahan, tenaga kerja dan uang). Pengertian produktivitas selanjutnya dijelaskan oleh Ardana (Ardana, 2012) merupakan produktivitas dipengaruhi oleh faktor seperti pendidikan, keterampilan, disiplin, etika kerja, motivasi, giji dan kesehatan, tingkat 
penghasilan, jaminan sosial, lingkungan dan iklim kerja, teknologi, sarana produksi dan manajemen.

Produktivitas (Sedarmayanti, 2001) mempunyai dua dimensi yang berbeda yaitu efektivitas dan efisensi, dimensi pertama efektivitas berhubungan dengan pencapaian supaya bekerja dengan maksimal, dimensi kedua efisiensi yaitu berhubungan dengan upaya membandingkan masukan dengan realisasi penggunaannya atau cara pekerjaan tersebut dikerjakan.

Produktivitas sangat dipengaruhi oleh beberapa faktor, yaitu sebagai berikut:

1. Knowledge (pengetahuan)

2. Skill (keterampilan)

3. Abilities (kemampuan)

4. Attitudes (sikap)

5. Behaviors (perilaku)

Produktivitas minyak nilam dapat meningkatkan kesejahteraan masyarakat, kegiatan produktivitas akan selalu mendapatkan keuntungan dari peningkatan dari segi kekuatan agar menghasilkan lebih banyak barang dan jasa. Peningkatan produktivitas akan meningkatkan secara langsung pada standar hidup yang berada dibawah kondisi distribusi yang sama dari perolehan produktivitas yang imbang dengan masukan tenaga kerja.

Islam Merupakan agama yang kaffah dimana mengatur serta memberi tuntunan tidak hanya dalam bidang ibadah saja akan tetapi juga dalam bidang laiinya seperti bekerja dan meningkatkan produktivitas untuk meningkatkan kesejahteraan. Konsep produktivitas menurut perspektif ekonomi Islam bukan hanya dalam bentuk materi saja tetapi juga dalam bentuk immateri seperti kesehatan jasmani dan rohani. Ukuran produktivitas bukan hanya dari penambahan dalam nilai ekonomi saja namun juga ada penambahan kebahagiaan yang didapatkan.

Kondisi era globalisasi sekarang ini, menuntut kita manusia agar menunjukkan etos kerja untuk meningkatkan produktivitas tidak hanya dengan modal rajin, giat, setia dan kerja keras (Ghozali, 2017), namun juga harus menerapkan nilai-nilai yang telah diatur oleh agama dalam Al-quran, Hadits, Ijma' dan Qiyas sebagai pedoman atau aturan main dalam bekerja untuk mendapatkan keberkahan dan mampu menafkahi keluarga dengan cara yang baik.

Salah satu perbedaan antara Ekonomi Islam dengan ekonomi lainnya yaitu mempercayai kehidupan setelah mati yaitu dunia akhirat, dengan pertimbangan tersebut maka produktivitas bukan semata-mata kebahagiaan dunia saja melainkan juga kebahagiaan akhirat. Dengan begitu maka kebahagiaan dunia akhirat harus dijalani oleh semua individu sehingga untuk menjalani kehidupan tersebut didunia harus dapat memenuhi kebutuhan dunia dan akhirat.

Dalam Ekonomi Islam bukan sekedar menganggap kerja sebagai pendorong utama aktivitas perekonomian, namun lebih dari itu dikarenakan kerja yaitu sebuah perbuatan yang sangat mulia untuk mewujudkan kemaslahatan individu dan masyarakat pada umumnya. Dalam perspektif ekonomi Islam menjadi sebuah keharusan oleh seorang muslim sebagai kewajiban dan dipandang sebagai nilai ibadah bagi yang melakukannya. Sehingga segala bentuk pengangguran, termasuk meminta-minta dipandang sebagai sebuah perbuatan tercela karena dapat memudharatkan diri sendiri.

Konsep zuhud dan tawakkal jika salah dipahami, maka seakan-akan agama Islam menyuruh dalam kemiskinan. Padahal jika dikaji lebih lanjut banyak sekali dalil Alquran dan Hadits yang mengajarkan kehidupan seorang muslim untuk meningkatkan produktivitas dalam bekerja agar dapat menafkahi keluarganya serta 
dapat membantu masyarakat lainnya.

Gampong Sido Muliyo terbentuk pada tahun 1945. Proses terbentuknya bahkan dimulai sejak tahun 1943, dimana pada saat tersebut Negara sedang dalam masa penjajahan. Setelah indonesia merdeka sebagai daerah yang terletak di pendalaman Aceh, Gampong Sido Mulyo mengalami pasang surut akibat terjadinya konflik bersenjata yang berkepanjangan. Sekarang ini dengan kondisi keamanan yang sudah membaik menjadi momentum bagi pemerintahan dan masyarakat untuk memajukan desa dengan berbagai program diantara lain seperti menanam dan mengolah minyak nilam untuk menuju masyarakat yang adil, makmur, sejahtera dan bermartabat (Mulyo, 2021).

Nilam merupakan salah satu potensi usaha yang dilakukan oleh masyarakat dengan harapan dapat meningkatkan dan mensejahterakan kehidupan mereka. Namun petani nilam masih mengalami kendala dalam hal menanam serta mengolah nilam tersebut agar menjadi sebuah produk yang laku untuk dipasarkan sehingga volume produksi nilam semakin tinggi dan meningkatkan produktivitas masyarakat desa tersebut.

Produksi usaha minyak nilam yang dilakukan oleh para petani/pekebun di Desa Sido Mulyo Kecamatan Kuta Makmur Kabupaten Aceh Utara masih hanya sebatas produksi minyak mentah yaitu minyak nilam mentah dari hasil penyulingan daun nilam. Berdasarkan hasil wawancara dengan ketua kelompok tani mengungkapkan bahwa produksi nilam yang saat ini dilakukan hanya sebatas penyulingan hasil pertanian daun nilam untuk menghasilkan minyak nilam, selanjutnya kelompok tani maupun petani yang ada di Desa Sido Mulyo Kecamatan Kuta Makmur Kabupaten Aceh Utara tidak melakukan inovasi dari produksi minyak nilam mentah tersebut dikarenakan minimnya pengetahuan yang dimiliki oleh sumber daya manusia serta kurangnya modal dalam membuat inovasi dan kreatifitas dalam produk minyak nilam.

Modal merupakan salah satu bagian dari faktor produksi yang sangat mempengaruhi produktivitas dari kelanjutan usaha tersebut. Penyulingan yang terdapat di desa Sido Mulyo hanya terdapat satu, tentunya jika ada penambahan alat penyulingan maka akan meningkatkan produktivitas dari minyak nilam tersebut sehingga proses produksi akan berjalan dengan lancar. Usaha kelompok tani yang berada di desa tersebut merupakan usaha yang dibentuk dari desa. Modal yang diterima kelompok tani dari dana desa, jika dana tersebut bisa dikelola dengan baik untuk penanaman nilam dari sumber usaha tani kemudian permodalan alat penyulingan ditambah, maka produkttivitas usaha minyak nilam akan mengalami peningkatan.

Kualitas dan kuantitas produksi sangat ditentukan oleh tenaga kerja. Oleh karena itu tenaga kerja adalah sumber kekayaan yang sangat penting di antara sumber-sumber ekonomi yang lainnya. Hubungan kerja antara pengusaha (Manajer Muslim) dengan karyawannya, selalu dilandasi oleh rasa kasih sayang, saling membutuhkan dan tolong-menolong. Pengusaha menjadi penolong bagi karyawan dalam hal menyediakan lapangan kerja. Karyawan menerima rezeki berupa upah dari hasil kerja kerasnya. Dengan demikian pula karyawan memberikan tenaga dan kemampuannya untuk membantu menyelesaikan pekerjaan yang diamanahkan oleh atasan, sehingga atasannya dapat menerima rezeki berupa laba berkat kerjasama dengan bawahan (Said, 2008).

Produktivitas minyak nilam di Aceh 
perlu ditingkatkan apalagi kualitas nilam di Aceh diakui oleh Negara Lain, seharusnya ini menjadi peluang bagi pemerintah dan masyarakat dalam meningkatkan nilam dengan kualitas yang dimiliki. Ada beberapa kendala yang dihadapi oleh petani nilam dalam meningkatkan produktivitas minyak nilam antara lain yaitu kurangnya pengetahuan mengetahui teknologi sehingga berdampak terhadap penurunan produksi dan kualitas nilam tersebut, selanjutnya perbaikan dalam pengolahan bahan baku dan proses penyulingan sehingga menjadi minyak nilam yang berkualitas.

Selanjutnya (Emmyzar, 2006) mengungkapkan bahwa beberapa faktor yang mempengaruhi penurunan produktivitas nilam di Indonesia selain teknologi dan pengolahan bahan baku yaitu mutu genetik tanaman, bibit yang kurang baik, pengelolaan manajemen yang kurang baik dan proses penyulingan yang masih kurang baik.

Untuk mencapai produktivitas maksimal dalam sebuah usaha maka diperlukan 3 faktor, yaitu:

1. Produktivitas berkaitan erat dengan waktu, waktu berhubungan dengan pembuatan jadwal kerja menurut persentase waktu yang digunakan, seperti kapan sebuah usaha harus dimulai, ditingkatkan dan berhenti jika ada kendala. Dalam hal ini misalnya kapan kegiatan produksi nilam dilakukan untuk mendapatkan hasil yang maksimal.

2. Produktivitas juga berhubungan dengan sumber daya manusia seperti kondisi, iklim dan suasana kerja yang baik dan nyaman.

3. Produktivitas berkaitan dengan sarana dan prasana. Dalam hal ini diperlukan seperti lahan, modal dan penambahan mesin penyulingan untuk meningkatkan produktivitas minyak nilam.

Islam mengajarkan untuk ummatnya agar melakukan produktivitas dan memiliki peran dalam berbagai bidang ekonomi, dalam melakukan pekerjaan di dunia dapat menjadi bagian daripada ibadah dan juga sebagai jihad. Dengan melakukan sebuah pekerjaan, maka kita dapat menafkahi keluarga dan dapat berbuat baik kepada tetangga dan masyarakat lainnya.

\section{KESIMPULAN}

1. Produktivitas memiliki artian efektivitas untuk mencapai kerja yang maksimal dan efisiensi untuk membandingkan input untuk mewujudkan penggunaannya. Produksi Nilam yang saat ini dilakukan oleh masyarakat Sido Mulyo sebatas penanaman nilam serta olahan hasil daun nilam untuk menghasilkan minyak nilam, selanjutnya kelompok tani dan petani tidak melakukan inovasi dalam meningkatkan produktivitas dari minyak nilam mentah tersebut dikarenakan kurangnya pengetahuan serta manajemen sumber daya manusia terkait produksi dari daun nilam.

2. Dalam Ekonomi Islam produktivitas sangat dianjurkan dalam dunia usaha untuk memaksimalkan waktu dan tenaga kerja dalam meningkatkan kesejahteraan baik untuk dirinya maupun untuk orang lain, namun tidak dengan menghalalkan segala cara. Prinsip-prinsip Ekonomi Islam harus diterapkan agar mendapatkan keberkahan dan keridhaan dari Allah SWT. 


\section{DAFTAR PUSTAKA}

Anwar, M. K. (2020). Produktivitas Dalam Perspektif Ekonomi Islam. BISEI: Jurnal Bisnis Dan Ekonomi Islam, $5(1), 2$.

Ardana. (2012). Manajemen Sumber Daya Manusia. Yogyakarta: Graha Ilmu.

Emmyzar, N. d. (2006). Budidaya Tanaman Nilam. Bogor: Pusat Penelitian dan Pengembangan Perkebunan.

Ghozali, K. F. (2017). Analisis Konsep Produktivitas Kerja Konvensional Dalam Pandangan Islam. Al Tijarah, 3(1), 6 .

Muhammad. (2004). Ekonomi Mikro dalam Perspektif Islam. Yogyakarta: BPFE.

Mulyo, D. S. (2021). Dokumentasi RPJMG Gampong Sido Muliyo.

Pertanian, K. (2021, Oktober). Data Lima
Tahun Terakhir. Diambil kembali dari Kementerian Pertanian Republik Indonesia:

https://www.pertanian.go.id/

Rianto, M. N. (2010). Teori Mikro Ekonomi. Jakarta: Kencana.

Said, M. (2008). Pengantar Ekonomi Islam. Pekanbaru: Suska Press.

Sedarmayanti. (2001). Produktivtas kerja karyawan. Bandung: Mandar Maju.

Soetomo. (2012). Keswadayaan Masyarakat Manifestasi Kapasitas Masyarakat untuk Berkembang Secara Mandiri. Yogyakarta: Pustaka Pelajar.

Syahrial. (2021, Oktober 10). Minyak Nilam Aceh Harus Terjaga Kualitasnya. Diambil kembali dari Waspada.id: https://waspada.id/aceh/ 